\title{
Optimization of Internal Mixing Parameter on the Electrical Conductivity of Multiwall Carbon Nanotubes/Synthetic Graphite/Epoxy Nanocomposites for Conductive Polymer Composites Using Taguchi Method
}

\author{
(Pengoptimuman Parameter Pencampur Dalaman terhadap Kekonduksian Elektrik bagi Nanotuib Karbon Berbilang \\ Dinding/Grafit Sintetik/Epoksi Nanokomposit untuk Komposit Polimer Pengalir Menggunakan Kaedah Taguchi) \\ Irmayani* \\ Department of Industrial Engineering, Universitas Ekasakti, Indonesia \\ Hendra Suherman \\ Department of Mechanical Engineering, Universitas Bung Hatta, Indonesia
}

\begin{abstract}
Conductive polymer composites (CPCS) can be widely uses as electronic devices, artificial muscles, solar energy conversion, and sensors. Nevertheless, CPCS has a low electrical conductivity. Therefore this study focused to improved the electrical conductivity of CPCS by optimizing the internal mixing parameter using Taguchi Method. Multiwall carbon nanotubes (MWCNTS) as secondary filler and synthetic graphite (SG) as primary filler use in this study. The CPCS composition are; $5 \mathrm{wt} \%$ MWCNTS; $75 \mathrm{wt} \% \mathrm{SG} ; 20 \mathrm{wt} \%$ epoxy resin as matrix. The internal mixing parameter applied as control factor in Taguchi Method analysis are mixing time, mixing temperature, and mixing rotation. Experiment was carried out based on orthogonal array design using these three internal mixing parameter. The results were analyzed using the signal to noise ratio $(S / N)$ and analysis of variance (ANOVA). The percent contribution of each internal mixing parameters to the electrical conductivity of MWCNTS/SG/epoxy resin were mixing rotation (44\%), mixing temperature (26\%) and mixing time (18\%). This was managed to reduce the number of voids and nano size particles conductive filler material (MWCNTS) more evenly dispersed in the epoxy resin. The optimum internal mixing parameters used to produce MWCNTS/SG/epoxy nanocomposites was effective to increase the electrical conductivity becomes $197 \mathrm{~S} / \mathrm{cm}$.
\end{abstract}

Keywords: Internal mixing parameters; Electrical conductivity; Taguchi Method; Analysis of Variance (ANOVA)

\section{INTRODUCTION}

Conductive polymer composites (CPCS) are a combination of conductive fillers and polymers as matrix. The CPCS properties depend on the materials conductive filler, matrix, and the manufacturing processes used in producing CPCS material. CPCs had a very wide attention from researchers because this material can be used for various applications (Kishi et al. 2004; Liao et al. 2008; Song et al. 2006; Ahmad et al. 2016). The main problem of CPCs is a low electrical conductivity. Some efforts were made to improve the electrical conductivity by adding a conductive material that has different size, shape, and loading concentration. Carbon based conductive filler such as carbon nanotubes (CNTs), carbon black (CB), graphite (G), carbon fibers (CF), and expanded graphite (EG) has been extensively used to improve the electrical conductivity of CPCs (Rybak et al. 2010; Lee et al. 2009; Antunes et al. 2011). Previous work by others researchers reported the mixing parmeters with short mixing time will improve the conductive networks formation (Hu et al. 2008). Meanwhile high speed mixing will also increase the dispersion of filler within polymer matrix (Xie et al. 2005). Thus a proper mixing parameters is needed to produce CPCs with good electrical conductivity. The internal mixer has been widely used in producing CPCs, because it has parameters such as temperature, rotation, and time that can be varied according to the process requirements. The optimum combination of internal mixer parameters is needed in producing CPCs with high electrical conductivity and suitable mechanical properties (Suherman et al. 2013; Zakaria et al. 2015). Taguchi method was required to reduce the number of experiments, cost, and time, to optimize manufacturing process in engineering applications (Asiltürk \& Akkuş 2011; Lin et al. 2000; Sulong et al. 2011; Wang \& Northwood. 2008). Taguchi method was developed to get optimal results with fewer number of specimens. Based on that condition, the Taguchi method using orthogonal arrays $(\mathrm{OA})$, signal to noise $(\mathrm{S} / \mathrm{N})$ ratio analysis and design of experiments (DOE) (Chang et al. 2011; Lin et al. 2009). Thus, this paper investigated the optimization of internal mixing parameter of MWCNTs/SG/epoxy nanocomposites on the electrical conductivity for conductive polymer composites (CPCS) using the Taguchi method.

\section{EXPERIMENTAL}

MATERIALS

In this study, two conductive filler namely multiwalled carbon nanotubes (MWCNTs) and synthetic graphite (SG) were used. 
MWCNTs was obtained from Nanocyl Carbon, Belgium. Based on manufacturer the properties of MWCNTs were; a diameter of $9.5 \mathrm{~nm}$, a length of $1.5 \mathrm{~mm}$, surface area of $300 \mathrm{~m}^{2} / \mathrm{g}$, and a purity of $90 \%$. SG with a surface area of $1.5 \mathrm{~m}^{2} / \mathrm{g}$ and a particle size of $74 \mu \mathrm{m}$ was obtained from Asbury Carbon, New Jersey, while the epoxy resin (635 thin epoxy resin) with a viscosity of 6 Poise obtained from the US Composites.

\section{FABRICATION OF MWCNTS/SG/EPOXY NANOCOMPOSITES}

The composition of multiwall carbon nanotubes (MWCNTs), synthetic graphite (SG) and epoxy used in this study are $5 / 75 / 20$ in weight percentage (wt.\%). The fabrication of MWCNTs/SG/epoxy nanocomposites consist of three stages. The first stages, to obtaine homogenous mixture, two conductive filler of MWCNTs and SG were mixed using ball mill. Steel balls used are made from stainless steel with a diameter of $10 \mathrm{~mm}$. The ratio of stainless steel balls with graphite and MWCNTs powder is 4:1. The time of ball milling process is one hour at $200 \mathrm{rpm}$. The second stages, resin and hardener were mixed using a high speed mixer model RM 20-KIKA-WERK at $1200 \mathrm{rpm}$ for 40 seconds. The ratio of resin and hardener is 3:1 in accordance with suggested by manufacturer. The third stages, the mixed filler and epoxy resin were further mixed using an internal mixer model Haake Rheomix at different mixing rotation $(20,25$, and $30 \mathrm{rpm})$, different mixing time $(5,10$, and $15 \mathrm{~min})$ and different mixing temperature $\left(30,35\right.$, and $\left.40^{\circ} \mathrm{C}\right)$. Then the MWCNTs/SG/epoxy nanocomposites mixture were poured into a steel mold at molding pressure of $1800 \mathrm{psi}$ and molding temperature of $150^{\circ} \mathrm{C}$ for 90 minutes.

\section{CHARACTERIZATION}

Jandel four point probe wit h RM3 test unit was used to measure the electrical conductivity of MWCNTs/SG/epoxy nanocomposites. Meanwhile, to investigate the dispersion of the primary and secondary conductive filler in the polymer matrix used field emission scanning electron microscopic (FESEM, Model Supra 55/55 VP).

\section{SELECTION OF CONTROL FACTORS}

The internal mixing parameter that need to be control are mixing rotation, mixing time and mixing temperature. Table. 1 show three control factors with three levels of internal mixing parameters; mixing rotation $\left(\mathrm{A}_{\mathrm{mr}}\right)=20,25$, and $30 \mathrm{rpm}$, mixing time $\left(\mathrm{B}_{\mathrm{mt}}\right)=5,10$, and $15^{\circ} \mathrm{C}$, and mixing temperature $\left(\mathrm{C}_{\mathrm{mtr}}\right)=30,35,40$ minutes.

TABLE 1. Control factor and level of internal mixing parameter

\begin{tabular}{clcccc}
\hline \multirow{2}{*}{ Symbol } & Control Factors & Unit & \multicolumn{3}{c}{ Level } \\
\cline { 4 - 6 } & & & 1 & 2 & 3 \\
\hline $\mathrm{A}_{\mathrm{mr}}$ & Mixing Rotation & Rpm & 20 & 25 & 30 \\
$\mathrm{~B}_{\mathrm{mt}}$ & Mixing Time & Min & 5 & 10 & 15 \\
$\mathrm{C}_{\mathrm{mtr}}$ & Mixing Temperature & ${ }^{\circ} \mathrm{C}$ & 30 & 35 & 40 \\
\hline
\end{tabular}

Mixing rotation $\left(\mathrm{A}_{\mathrm{mr}}\right)$ serves to produce a uniform mixture of conductive filler in the polymer matrix. $\mathrm{Hu}$ et al. (2008) found that high speed of mixing rotation $\left(\mathrm{A}_{\mathrm{mr}}\right)$ is not required to obtain an evenly mixture of conductive filler material. Thus, the different mixing rotation $\left(\mathrm{A}_{\mathrm{mr}}\right)$ that selected to optimize the process parameters of the internal mixing in producing MWCNTs/SG/epoxy nanocomposites were increased from the lowest rotation, at 20, 25 and $30 \mathrm{rpm}$. Mixing time $\left(\mathrm{B}_{\mathrm{mt}}\right)$ used to produce MWCNTs/sG/ epoxy nanocomposites are also effective to improve the dispersion of the conductive filler within epoxy resin, so that increased the electrical conductivity of MWCNTs/SG/epoxy nanocomposites produced (Kalyon et al. 2002). Therefore, the mixing time $\left(\mathrm{B}_{\mathrm{m}}\right)$ selected are 5, 10 and 15 minutes. The MWCNTs/SG/epoxy nanocomposites mixture begins to harden at 20 minutes mixing time. Mixing temperature $\left(\mathrm{C}_{\mathrm{mtr}}\right)$ serves to reduce the viscosity of the polymer matrix material so that the electrical conductivity of the network will be easily formed (Das et al. 2002). Therefore, the mixing temperature level of the internal mixing parameters were increased from 30,35 and $40^{\circ} \mathrm{C}$.

\section{THE ORTHOGONAL ARRAY (OA) L9 $\left(3^{3}\right)$ OF THE INTERNAL MIXING PARAMETERS}

The study was conducted by providing nine plates dimensions $100 \mathrm{~mm} \times 100 \mathrm{~mm} \times 2.5 \mathrm{~mm}$. The number of MWCNTs/sG/ epoxy nanocomposites plates provided based on the factors and levels of internal mixing parameters as shown in Table 2. The composition of orthogonal L9 $\left(3^{3}\right)$ with nine runs total experiments is to get a set of the optimum internal mixing parameters. Although nine runs is the minimum number of runs for three control factors and three levels, but this minimum runs managed to set a combination of optimum parameters for a study of three control factors and three levels (Liu et al. 2010; Surace et al. 2010; Sulong et al. 2011).

TABLE 2. The Orthogonal array L9 $\left(3^{3}\right)$ of the internal mixing parameters

\begin{tabular}{cccc}
\hline \multirow{2}{*}{ Number of Experiment } & \multicolumn{3}{c}{ Control Factor and Levels } \\
\cline { 2 - 4 } & A & B & C \\
\hline 1 & 20 & 5 & 30 \\
2 & 20 & 10 & 35 \\
3 & 20 & 15 & 40 \\
4 & 25 & 5 & 35 \\
5 & 25 & 10 & 40 \\
6 & 25 & 15 & 30 \\
7 & 30 & 5 & 40 \\
8 & 30 & 10 & 30 \\
9 & 30 & 15 & 35 \\
\hline
\end{tabular}




\section{RESULTS AND DISCUSSION}

\section{THE ELECTRICAL CONDUCTIVITY OF MWCNTS/SG/EPOXY NANOCOMPOSITE}

The electrical conductivity of MWCNTs/SG/epoxy nanocomposite for number of experiment 1 to 9 were measured in three different areas of the far right, middle, and left end of each sample produced. The electrical conductivity of MWCNT/SG/epoxy nanocomposites for any tests show in Table 3. The highest average value of the electrical conductivity and the signal to noise ratio $(\mathrm{S} / \mathrm{N})$ obtained on the running number three $(191 \mathrm{~S} / \mathrm{cm}$ and $45.64 \mathrm{~dB})$ with a set combination of internal mixing parameters $\left(\mathrm{A}_{1-\mathrm{mr}}(20 \mathrm{rpm})\right.$, $\mathrm{B}_{3-\mathrm{mt}}(15 \mathrm{~min})$, and $\mathrm{C}_{3-\mathrm{mtr}}\left(40^{\circ} \mathrm{C}\right)$. The lowest average value of the electrical conductivity and signal to noise ratio obtained on the running number seven $(122 \mathrm{~S} / \mathrm{cm}$ and $41,75 \mathrm{~dB})$ with a set combination of internal mixing parameters are $\left(A_{3-m}\right.$ (30 rpm), $\mathrm{B}_{1-\mathrm{mt}}(5 \mathrm{~min})$, and $\mathrm{C}_{3-\mathrm{mtr}}\left(40^{\circ} \mathrm{C}\right)$.

TABLE 3. The electrical conductivity of the internal mixing parameters of MWCNTs/SG/epoxy nanocomposites based on orthogonal array L9 $\left(3^{3}\right)$

\begin{tabular}{|c|c|c|c|c|c|}
\hline \multirow{2}{*}{ Number of experiment } & \multicolumn{3}{|c|}{ Control factors and levels } & \multirow{2}{*}{$\begin{array}{l}\text { Electrical conductivity } \\
(\mathrm{S} / \mathrm{cm})\end{array}$} & \multirow{2}{*}{$\mathrm{S} / \mathrm{N}(\mathrm{dB})$} \\
\hline & $\mathrm{A}(\mathrm{rpm})$ & $\mathrm{B}(\min )$ & $\mathrm{C}\left({ }^{\circ} \mathrm{C}\right)$ & & \\
\hline 1 & 20 & 5 & 30 & 153 & 43.71 \\
\hline 2 & 20 & 10 & 35 & 190 & 45.57 \\
\hline 3 & 20 & 15 & 40 & 191 & 45.64 \\
\hline 4 & 25 & 5 & 35 & 155 & 43.80 \\
\hline 5 & 25 & 10 & 40 & 151 & 43.56 \\
\hline 6 & 25 & 15 & 30 & 138 & 42.78 \\
\hline 7 & 30 & 5 & 40 & 122 & 41.75 \\
\hline 8 & 30 & 10 & 30 & 135 & 42.62 \\
\hline \multirow[t]{4}{*}{9} & 30 & 15 & 35 & 174 & 44.78 \\
\hline & & & Avg & 157 & \\
\hline & & & Max & 191 & \\
\hline & & & Min & 122 & \\
\hline
\end{tabular}

Data obtained in Figure 1 and Figure 2 shows the effect of three control factors and levels used on the optimization of the internal mixing parameter. The optimum parameter of internal mixer of MWCNT/SG/epoxy nanocomposites obtained through the combined set of mixing rotation $\left(\mathrm{A}_{1-\mathrm{mr}}(20 \mathrm{rpm})\right)$ mixing time $\left(\mathrm{B}_{3-\mathrm{mt}}(15 \mathrm{~min})\right.$, and mixing temperature $\left(\mathrm{C}_{2-\mathrm{mtr}}\right.$ $\left.\left(35^{\circ} \mathrm{C}\right)\right)$. The average of electrical conductivity (Figure 1) and signal to noise ratio $(\mathrm{S} / \mathrm{N})$ of the internal mixer control parameter (Figure 2) show that higher mixing rotation $\left(\mathrm{A}_{\mathrm{mr}}\right)$ of 25 and $30 \mathrm{rpm}$ resulting the lower electrical conductivity compare than MWCNT/SG/epoxy nanocomposites generated by the lower mixing rotation at $20 \mathrm{rpm}$. This is due to the higher mixing rotation will damage the electrical conductivity tissue between conductive filler in a polymer matrix (Hu et al. 2008). Therefore, increasing of mixing rotation will lower the electrical conductivity obtained from the MWCNT/SG/epoxy nanocomposites produced.

The increasing of mixing time $\left(\mathrm{B}_{\mathrm{mt}}\right)$ from 5,10 and 15 minutes are effective to increase the electrical conductivity obtained. This is because a longer time is required in the electrical conductivity network formation between conductive filler in a polymer matrix. Hu et al. (2008) also found that the increasing of mixing time will increase the electrical conductivity tissue of the composite material produced, so that the electrical conductivity obtained will be higher than the composite material produced in a shorter time.
The increasing of mixing temperature $\left(\mathrm{C}_{\mathrm{mtr}}\right)$ from 30 to $35^{\circ} \mathrm{C}$ are effective to increase the electrical conductivity of MWCNT/SG/epoxy nanocomposites generated, but the electrical conductivity of MWCNT/SG/epoxy nanocomposites decreased significantly at higher temperatures $\left(40^{\circ} \mathrm{C}\right)$. This was due to mixture of conductive fillers and binders started to harden or cross linked at a temperature of $40^{\circ} \mathrm{C}$.

\section{ANALYSIS OF VARIANCE OF INTERNAL MIXING MWCNTS/SG/EP NANOCOMPOSITE}

Analysis of Variance (ANOVA) using statistical method to separate the individual effect of control factors. The percentage contribution of each control factor were used to measure the internal mixing parameters effect on the electrical conductivity of MWCNT/SG/epoxy nanocomposites generated.

The analysis of variance (ANOVA) result for internal mixing experimental parameters are shown in Table 4. All predetermined factors shows the highest significant level, with $\alpha=0.005(99.5 \%$ confidence level $)$ of the mixing rotation $\left(\mathrm{A}_{\mathrm{mr}}\right)$, mixing time, $\left(\mathrm{B}_{\mathrm{mt}}\right)$ and mixing temperature $\left(\mathrm{C}_{\mathrm{mtr}}\right)$. Mixing rotation $\left(\mathrm{A}_{\mathrm{mr}}\right)$ contributed the largest percentage (44\%) for the electrical conductivity properties of MWCNT/ SG/epoxy nanocomposites produced, followed by mixing temperature $\left(\mathrm{C}_{\mathrm{mtr}}\right)$ of $27 \%$ and mixing time $\left(\mathrm{B}_{\mathrm{mt}}\right)(18 \%)$. 


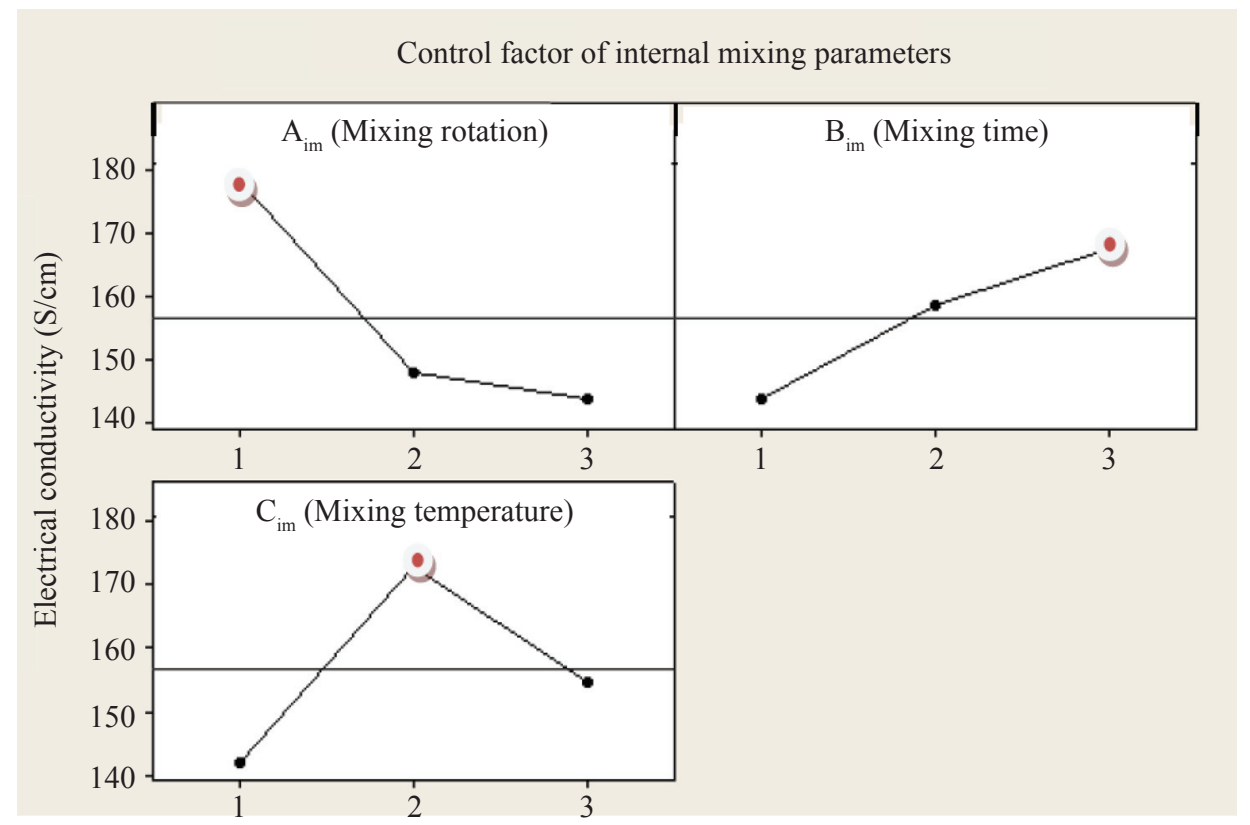

FIGURE 1. Effect of internal mixing parameter on the electrical conductivity of MWCNTS/SG/epoxy nanocomposites

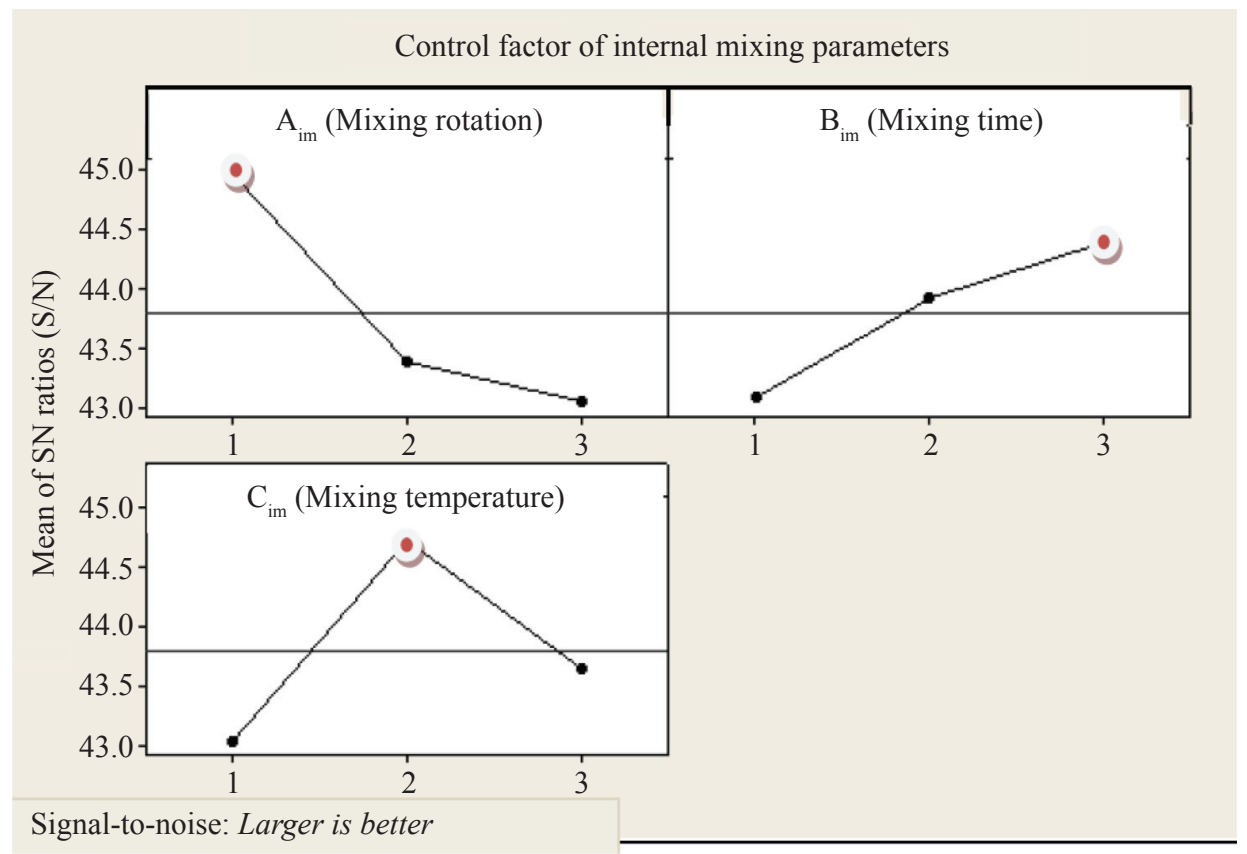

FIGURE 2. Effect of internal mixing parameter on $\mathrm{S} / \mathrm{N}$ ratio averages of MWCNTS/sG/epoxy nanocomposites

TABLE 4. Analysis of variance (ANOVA) on the electrical conductivity of MWCNT/SG/epoxy nanocomposites

\begin{tabular}{|c|c|c|c|c|c|c|}
\hline Factor & $\begin{array}{l}\text { Degree of } \\
\text { Freedom } \mathrm{f}_{\mathrm{n}}\end{array}$ & $\begin{array}{r}\text { Sum of } \\
\text { Square } S_{n}\end{array}$ & Variance $\mathrm{V}_{\mathrm{n}}$ & $\begin{array}{l}\text { Variance } \\
\text { Ratio } F_{n}\end{array}$ & $\begin{array}{c}\text { Critical Value } \\
\text { F }\end{array}$ & $\begin{array}{c}\text { Percentage } \\
\text { Contribution } \mathrm{P}_{\mathrm{n}}\end{array}$ \\
\hline $\mathrm{A}$ & 2 & 6396 & 3198 & 49 & $\mathrm{~F}_{(0.005 ; 2 ; 20)}: 6.99$ & 44 \\
\hline $\mathrm{B}$ & 2 & 2649 & 1325 & 20 & $\mathrm{~F}_{(0.005 ; 2 ; 20)}: 6.99$ & 18 \\
\hline $\mathrm{C}$ & 2 & 3786 & 1893 & 29 & $\mathrm{~F}_{(0.005 ; 2 ; 20)}: 6.99$ & 26 \\
\hline Error & 20 & 1318 & 66 & & & 12 \\
\hline Total & 26 & 14150 & & & & 100 \\
\hline
\end{tabular}


A bigger contribution from the mixing rotation was due to the dispersion and distribution of conductor filler, specially the secondary conductive filler in the polymer matrix. Good dispersion of the conductive filler in the polymer matrix increases the conductivity network and the electrical conductivity of MWCNT/SG/epoxy nanocomposites. Evenly dispersion of conductive filler in the polymer matrix could improve network conductive path and the electrical conductivity of MWCNTS/SG/epoxy nanocomposites produced (Antunes et al. 2011; Ma et al. 2009; Lee et al. 2009). Analysis of variance (ANOVA) error, ie $12 \%$, show that there are no significant factors are missed in Taguchi approach.

\section{VERIFICATION TESTS OF MWCNTS/SG/EPOXY NANOCOMPOSITE}

Verification test is the last step to identify Taguchi method impact for each experimental parameters. Confirmatory tests can be done in two ways; using forecast equation $\left(\eta_{\text {forecast }}\right)$ and experimental verification of the optimum parameters obtained from the signal to noise ratio $(\mathrm{S} / \mathrm{N})$ for the internal mixing parameters, namely parameters $\mathrm{A}_{1-\mathrm{mr}}, \mathrm{B}_{3-\mathrm{mt}}, \mathrm{C}_{2-\mathrm{mtr}}$. Forecast equations to predict the electrical conductivity and signal to noise ratio $(\mathrm{S} / \mathrm{N})$ for the optimum internal mixing parameter, using Equation 1 (Liu et al. 2010).

$$
\eta_{\text {forecast }} \text { optimum }=T+\left(\mathrm{A}_{1}-T\right)+\left(\mathrm{B}_{3}-T\right)+\left(\mathrm{C}_{2}-T\right)
$$

$T=$ The average value of signal to noise ratio $(\mathrm{S} / \mathrm{N})$ or the electrical conductivity average obtained from the experimental. The optimum combination of parameters $A_{1-\text {-im }}, B_{3-\text { im }}, C_{2-\text { im }}$ is the average signal to noise ratio $(\mathrm{S} / \mathrm{N})$ or the electrical conductivity average of MWCNTs/SG/epoxy nanocomposites for each significant level. The optimum $\eta_{\text {forecast }}$ are $205 \mathrm{~S} / \mathrm{cm}$ and $46 \mathrm{~dB}$. The experimental study then conducted to set the optimum electrical conductivity and signal to noise ratio (S/N) of MWCNTs/SG/epoxy nanocomposites. Experiments conducted by provide a sample of the optimum internal mixing parameters combination, mixing rotation $(20 \mathrm{rpm})$, mixing time (15 $\mathrm{min})$, and mixing temperature $\left(35^{\circ} \mathrm{C}\right)$.

The results of the initial combination, optimum combination, and optimum $\eta_{\text {forecast }}$ are shown in Table 5 . The average value of the electrical conductivity and signal to noise ratio for the initial combination parameter of $A_{1}$ ${ }_{\mathrm{m},}, \mathrm{B}_{1-\mathrm{mt}}$, and $\mathrm{C}_{1-\mathrm{mtr}}$, are $153 \mathrm{~S} / \mathrm{cm}$ and $44 \mathrm{~dB}$. The optimum combination parameter of $\mathrm{A}_{1-\mathrm{mr}} \mathrm{B}_{3-\mathrm{mt}} \mathrm{C}_{2-\mathrm{mtr}}$ produce MWCNTs/ SG/epoxy nanocomposites with the electrical conductivity and the signal to noise ratio $\mathrm{S} / \mathrm{N}$ average values of $197 \mathrm{~S} / \mathrm{cm}$ and $46 \mathrm{~dB}$. The confirmation test of the optimum parameter combination managed to increase the electrical conductivity of MWCNTS/SG/epoxy nanocomposites obtained as $28 \%$. Field emission scanning electron microscopic (FESEM) images on the experimental confirmation shows that the number of voids (Figure 3c and 3d) was significantly reduced and conductive filler (MWCNTS) as a second filler material dispersed better in the whole area epoxy resin as a matrix. The electrical conductivity of MWCNTs/SG/epoxy nanocomposites obtain is much higher than the initial combination (Figure $3 \mathrm{a}$ and $3 b)$ The electrical conductivity and signal to noise $(\mathrm{S} / \mathrm{N})$ ratio from the experimental results were not significantly different with the optimum of $\eta_{\text {forecast }}$, which are only as much as $4.47 \%$ and $1.35 \%$. These results show that the forecast equations used was effective to predict the electrical conductivity and signal to noise ratio $(\mathrm{S} / \mathrm{N})$ to get the optimum parameter combination of MWCNT/SG/epoxy nanocomposites.
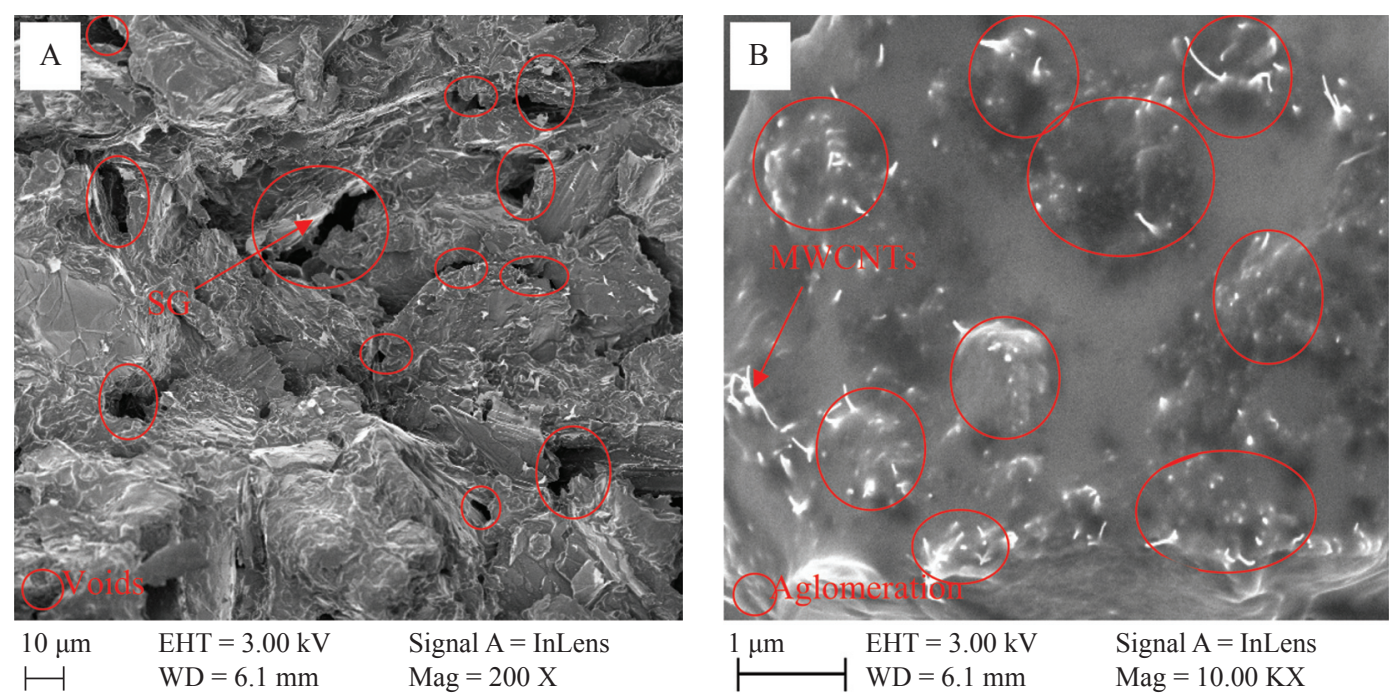

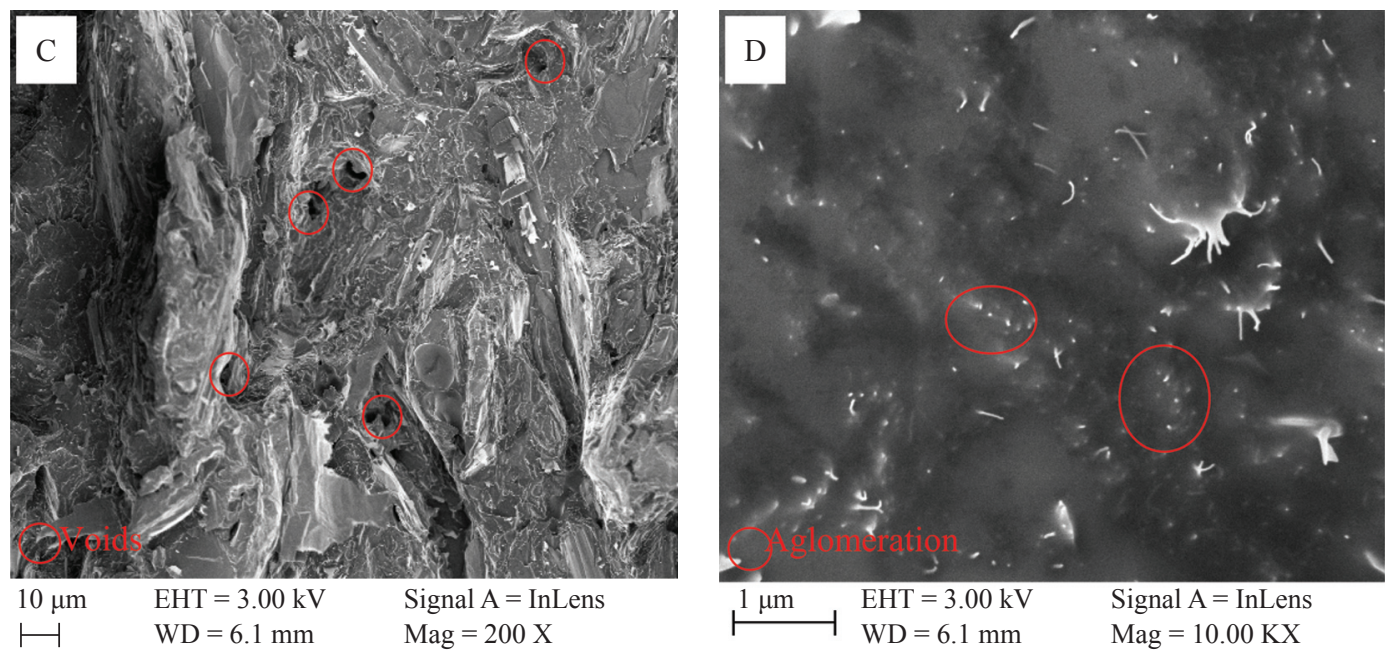

FIGURE 3. SEM images of MWCNT/SG/Epxy nanocomposites on fracture surface of initial experimen $(\mathrm{a}, \mathrm{b})$ and confirmation experimen $(\mathrm{c}, \mathrm{d})$ internal mixing parameters

TABLE 5 . The optimization of the electrical conductivity of MWCNT/SG/epoxy nanocomposites

\begin{tabular}{lccc}
\hline & Level & Electrical Conductivity $(\mathrm{S} / \mathrm{cm})$ & S/N Ratio \\
\cline { 3 - 4 } & & Average & $(\mathrm{dB})$ \\
\hline Initial Combination & $\mathrm{A}_{1-\mathrm{mr}} \mathrm{B}_{1-\mathrm{mt}} \mathrm{C}_{1-\mathrm{mtr}}$ & 153 & 44 \\
Optimum Combination & $\mathrm{A}_{1-\mathrm{mr}} \mathrm{B}_{3-\mathrm{mt}} \mathrm{C}_{2-\mathrm{mtr}}$ & 197 & 45 \\
Optimum $\eta_{\text {forecast }}$ & $\mathrm{A}_{1-\mathrm{mr}} \mathrm{B}_{3-\mathrm{mt}} \mathrm{C}_{2-\mathrm{mtr}}$ & 205 & 46 \\
\hline
\end{tabular}

Mixing rotation $20 \mathrm{rpm}\left(\mathrm{A}_{1-\mathrm{mr}}\right)$; Mixing time $15 \mathrm{~min}\left(\mathrm{~B}_{3-\mathrm{mt}}\right)$; Mixing temperature $35^{\circ} \mathrm{C}\left(\mathrm{C}_{2-\mathrm{mtr}}\right)$

CONCLUSION

Based on the optimization of the internal mixing parameters on the electrical conductivity of MWCNTs/SG/epoxy nanocomposites can be concludes as below:

1. Taguchi method has been successful in increasing the value of the electrical conductivity of $153 \mathrm{~S} / \mathrm{cm}$ (initial combination) to $195 \mathrm{~S} / \mathrm{cm}$ (optimum combination).

2 The highest percent contribution of the internal mixing parameters of the electrical conductivity MWCNTs/SG/ epoxy nanocomposites is mixing rotation (44\%).

3. Forecast equations is efective to predict the electrical conductivity and signal to noise ratio $(\mathrm{S} / \mathrm{N})$ for the optimum internal mixing parameter.

\section{ACKNOWLEDGEMENTS}

This work was supported by the Research Fund provided by the Directorate General of Higher Education, 2016 with contract number: SP DIPA-042.06.1.401516/2016, 7 December 2015, for Kopertis Wilayah X, number: 18/KontrakPenelitian/010/KM/2016, 22 February 2016.
REFERENCES

Ahmad, M.A.F., Nuawi, M.Z., Mohamed, N.F., Wahid, Z. \& Dirhamsyah, M. 2016. The study of polymer material characterisation using M-Z-N statistical analysis method. Jurnal Kejuruteraan 28: 9-18.

Antunes, R.A., de Oliveira, M.C.L., Ett, G. \& Ett, V. 2011. Carbon materials in composite bipolar plates for polymer electrolyte membrane fuel cells: A review of the main challenges to improve electrical performance. Journal of Power Sources 196: 2945-2961.

Asiltürk, İ. \& Akkuş, H. 2011. Determining the effect of cutting parameters on surface roughness in hard turning using the Taguchi method. Measurement 44: 16971704.

Chang, C.Y., Huang, R., Lee, P.C. \& Weng, T.L. 2011. Application of a weighted Grey-Taguchi method for optimizing recycled aggregate concrete mixtures. Cement and Concrete Composites 33: 1038-1049.

Das, N.C., Chaki, T.K. \& Khastgir, D. 2002. Effect of processing parameters, applied pressure and temperature on the electrical resistivity of rubber-based conductive composites. Carbon 40: 807-816.

Hu, N., Masuda, Z., Yamamoto, G., Fukunaga, H., Hashida, T. \& Qiu, J. 2008. Effect of fabrication process on electrical properties of polymer/multi-wall carbon nanotube nanocomposites. Composites Part A:Applied Science and Manufacturing 39: 893-903. 
Kalyon, D.M., Birinci, E., Yazici, R., Karuv, B. \& Walsh, S. 2002. Electrical properties of composites as affected by the degree of mixedness of the conductive filler in the polymer matrix. Polymer Engineering and Science 42: 1606-1612.

Kishi, H., Kuwata, M., Matsuda, S., Asami, T. \& Murakami, A. 2004. Damping properties of thermoplastic-elastomer interleaved carbon fiber-reinforced epoxy composites. Composites Science and Technology 64: 2517-2523.

Lee, J.H., Jang, Y.K., Hong, C.E., Kim, N.H., Li, P. \& Lee, H.K. 2009. Effect of carbon fillers on properties of polymer composite bipolar plates of fuel cells. Journal of Power Sources 193: 523-529.

Liao, S., Yen, C., Weng, C., Lin, Y., Ma, C., Yang, C., Tsai, M., Yen, M. Hsiao, M. \& Lee, S. 2008. Preparation and properties of carbon nanotube/polypropylene nanocomposite bipolar plates for polymer electrolyte membrane fuel cells. Journal of Power Sources 185: 1225-1232.

Lin, J.L., Wang, K.S., Yan, B.H. \& Tarng, Y.S. 2000. Optimization of the electrical discharge machining process based on the Taguchi method with fuzzy logics. Journal of Materials Processing Technology 102: 4855.

Lin, Y.C., Chen, Y.F., Wang, D.A. \& Lee, H.S. 2009. Optimization of machining parameters in magnetic force assisted EDM based on Taguchi method. Journal of Materials Processing Technology 209: 3374-3383.

Liu, Y.T., Chang, W.C. \& Yamagata, Y. 2010. A study on optimal compensation cutting for an aspheric surface using the Taguchi method. CIRP Journal of Manufacturing Science and Technology 3: 40-48.

Ma, P.C., Liu, M.Y., Zhang, H., Wang, S.Q., Wang, R., Wang, K., Wong, Y.K., Tang, B.Z., Hong, S.H., Paik, K.W. \& Kim, J.K. 2009. Enhanced electrical conductivity of nanocomposites containing hybrid fillers of carbon nanotubes and carbon black. ACS Applied Materials \& Interface, American Chemical Society 1: 1090-1096.

Rybak, A., Boiteux, G., Melis, F. \& G. Seytre. 2010. Conductive polymer composites based on metallic nanofiller as smart materials for current limiting devices. Composites Science and Technology 70: 410-416.

Song, L.N., Xiao, M. \& Meng, Y.Z. 2006. Electrically conductive nanocomposites of aromatic polydisulfide/ expanded graphite. Composites Science and Technology 66: 2156-2162.
Suherman, Hendra., Sahari, J., Sulong, A.B. 2013. Effect of small-sized conductive filler on the properties of an epoxy composite for a bipolar plate in a PEMFCs. Ceramis International 39: 7159-7166.

Sulong, A.B., Park, J., Azhari, C.H. \& Jusoff, K. 2011. Process optimization of melt spinning and mechanical strength enhancement of functionalized multi-walled carbon nanotubes reinforcing polyethylene fibers. Composites Part B: Engineering 42: 11- 17.

Surace, R., Filippis, L.A.C., Ludovico, A.D. \& Boghetich, G. 2010. Application of Taguchi method for the multiobjective optimization of aluminium foam manufacturing parameters. International Journal of Materials Forming 3: $1-5$.

Wang, Y. \& Northwood, D.O. 2008. Optimization of the polypyrrole-coating parameters for proton exchange membrane fuel cell bipolar plates using the Taguchi method. Journal of Power Sources 185: 226-232.

Xie, X., Mai, Y. \& Zhou, X. 2005. Dispersion and alignment of carbon nanotubes in polymer matrix: a review. Materials Science and Engineering: Reports 49: 89-112.

Zakaria, M.Y., Sulong, A.N., Sahari, J. \& Suherman, H. 2015. Effect of the addition of milled carbon fiber as secondary filler on the electrical conductivity of graphite/epoxy composite for electrical conductive material. Composite Part B 83: 75-80.

*Irmayani

Department of Industrial Engineering

Universitas Ekasakti, Padang

West Sumatera, Indonesia

Hendra Suherman

Department of Mechanical Engineering

Universitas Bung Hatta

25143 Padang, Indonesia

*Corresponding author; email: hendras@bunghatta.ac.id

Received Date: $13^{\text {th }}$ June 2017

Accepted Date: $15^{\text {th }}$ November 2017

In Press date: $15^{\text {th }}$ December 2017

Published date: $31^{\text {st }}$ December 2017 
